\title{
Chromium(VI) Heavy Metal Biosorption in Citarum River Water Sample Using Saccharomyces cerevisiae and Rhizopus oryzae Biomass
}

\author{
Suci Rizki Nurul Aeni*, Ni'matul Murtafi'ah, Handarini \\ Medical Laboratory Technology Division, Institut Kesehatan Rajawali \\ Jl. Rajawali Barat No. 73 Bandung, West Java, Indonesia. 40184 \\ *Email: sua.tieq@gmail.com
}

\begin{abstract}
The Citarum River was regarded as the World's dirtiest river in 2018, characterized by a Basin situated adjacent to several textile and electroplating industries. Hexavalent chromium metal $\left(\mathrm{Cr}^{6+}\right)$ is a toxic, carcinogenic heavy metal found in the wastes of these industries. Furthermore, biosorption with biological adsorbents, including Saccharomyces cerevisiae and Rhizopus oryzae, is an alternative method for treating water polluted with heavy metals. This study therefore aims to adsorb $\mathrm{Cr}^{6+}$ heavy metals from Citarum River water using S. cerevisiae and $R$. oryzae biomass in two locations: Nanjung and Pangauban, with various biomass concentration and stirring speeds. For this study, $0.25,0.5$, and $0.75 \mathrm{~g}$ of $R$. oryzae suspension, as well as 250,500 , and $750 \mu$ of $S$. cerevisiae were used as adsorbent, while rotated at speeds of $250 \mathrm{rpm}, 750 \mathrm{rpm}$ and $1500 \mathrm{rpm}$. Subsequently, the $\mathrm{Cr}^{6+}$ metal content was measured using a UV-Vis spectrophotometer at a wavelength of $525 \mathrm{~nm}$, and calculated based on a standard curve. The results showed $S$. cerevisiae and $R$. oryzae are able to reduce the levels of $\mathrm{Cr}^{6+}$ in Citarum river water. The most reduction was obtained with the highest concentration of the adsorbents, $750 \mu$ for $S$. cerevisiae and $0.75 \mathrm{~g}$ for $R$. oryzae, at the speed of $1500 \mathrm{rpm}$. S. cerevisiae and $R$. oryzae have great potential as biosorbents for the in situ remediation of Citarum River contaminated with heavy metals.
\end{abstract}

Keywords: biosorption; $\mathrm{Cr}^{6+}$ heavy metal; Nanjung; Pangauban; UV-Vis spectrophotometer

Articel History: Received 26 December 2019; Received in revised form 17 May 2020; Accepted 18 November 2020; Available online 30 December 2020

How to Cite This Article: Aeni SRN, Murtafi'ah N, Handarini H. 2020. Chromium(VI) heavy metal biosorption in Citarum River water sample using Saccharomyces cerevisiae and Rhizopus oryzae Biomass. Biogenesis: Jurnal Ilmiah Biologi. vol 8(2): 119-125. doi: https://doi.org/10.24252/bio.v8i2.12274.

\section{INTRODUCTION}

The industry 4.0 era led the government to expand the industrial sector, and the textile industry has been discovered to increase in number each year. According to the BPS Jawa Barat (2016), there were about 1062 textile companies within West Java, and most of these companies were located near Bandung Raya. The growth surge experienced in this sector had numerous effects, including rising in production waste (Putra, 2017; Sumantri et al., 2018), often leading to environmental challenges. Furthermore, industrial waste management is habitually ignored by these companies, leading to damage to the surrounding environment. The Citarum River, in this instance, is exposed to hexavalent chromium $\left(\mathrm{Cr}^{6+}\right)$ waste.

The study by Komarawidjaja (2016), Putra (2017), Sihombing (2020) reported damage to the aquatic environment to be as a result of pollution by industrial \& domestic waste in West Java, while Paramita (2017), Wardani (2018), Priyanto (2019) stated industrial effluents contain heavy metals and are therefore a major cause of water pollution. Textile, electroplating, dyeing, and photographic industries pollute water bodies with $\mathrm{Cr}^{6+}$, and this leads to acute poisoning (Zewail \& Yousef, 2014; Kim \& Kang, 2016), including vomiting (Kozlowski et al., 2014; Vellaichamy et al., 2017), diarrhea, and indigestion (Jabbo et al., 2016; Igberase et al., 2018; Li \& Han, 2019), as well as chronic poisoning, including skin and mucous membrane irritation (Ayob et al., 2016; Fasya, 2018), kidney and liver disorders, leading to lung cancer in industrial workers exposed to chromium (Kozlowski et al., 2014; Proctor et al., 2014; Das et al., 2015).

Industrial waste management is a complicated and expensive process. As a result, the government took action and developed a method to combat pollution degrading the Citarum River water quality. Thus, the LIPI (2019) designed a simpler and faster technique of monitoring the content of textile dyes to reduce the monitoring cost and the results 
obtained are of both national and international standards.

Biosorption is a safe, cost effective alternative for increasing the Citarum River water quality. Furthermore, the technique has a higher metal binding capacity (Chatterjee et al., 2010; Chojnacka, 2010), generates less deposit, recover it into less hazardous forms (Kilıç et al., 2014; Ayangbenro \& Babalola, 2017), and utilizes widely available and reusable raw materials (Gürel, 2017; Escudero et al., 2019). These benefits trigger the increasing efforts to clean water bodies exposed to metal ion waste and encourage further research in order to develop even cheaper, more effective, and efficient wastewater treatment techniques. Utilizing biosorption technique with biological materials is therefore a decent alternative for industrial waste management. Biomaterials, including algae (Son et al., 2018; Ameri et al., 2020), coconut and rice husk (Anirudhan et al., 2011; Gupta et al., 2011; Xu et al., 2013), also filamentous fungi (Dhankhar \& Hooda, 2011; Siddiquee et al., 2015), are effective heavy metal ions adsorbents and have been proven to possess maximum metal-ion absorption capacity.

The benefits of using microorganisms as biosorbents include low operational cost, efficient, high metal binding capacity, minimum deposits, reusability, ubiquity (Bakircioglu et al., 2011; Abbas et al., 2014; Xie et al., 2020). In fact, Saccharomyces cerevisiae and Rhizopus oryzae is an effective microorganism for biosorption (Fu et al., 2012; Gharieb et al., 2014; Farhan \& Khadom, 2015; Tahir et al., 2017; do Nascimento et al., 2019). Sources of $S$. cerevisiae include natural cultures, bioethanol plant waste and industrial waste containing carbon (Sathvika et al., 2018; Favaro et al., 2019). S. cerevisiae is also a potential material for effective absorption of heavy metals, as a result of the high percentage of cell wall material, serving as binding sites.

This study utilizes $S$. cerevisiae and $R$. oryzae for biosorption because the microorganisms' cell walls are composed of polysaccharides, proteins, lipids, chitin, and chitosan, with carboxylate, hydroxyl, sulfate, phosphate and amino functional groups. In addition, monovalent and divalent ions, including $\mathrm{Na}^{+}, \mathrm{Mg}^{+}$, and $\mathrm{Ca}^{2+}$, are present. These functional groups, particularly carboxylates and amines, are able to bind the metal ion $\mathrm{Cr}^{6+}$, consequently, enabling $S$. cerevisiae and $R$. oryzae to function effectively during biosorbtion. Meanwhile, stirring process is carried out to evenly distribute the biosorbents distributed, leading to maximum adsorbtion power. Stirring also helps to continuously renew the biosorbent interface concentration gradient using bulk biosorbent, hence, maintaining the adsorbtion process.

\section{MATERIALS AND METHODS}

Physical and chemical test of Citarum River water samples. The samples collected from Citarum River in two locations including Nanjung and Pangauban village. A total of $2 \mathrm{ml}$ of $\mathrm{H}_{2} \mathrm{SO}_{4}$ and $0.5 \mathrm{ml}$ 1.5-diphenylcarbazide are added to the $\mathrm{Cr}^{6+}$ standard solution (Lazo, 2009; Rice et al., 2017).

Rejuvenation and production of Saccharomyces cerevisiae and Rhizopus oryzae. A total of $0.25,0.5$ and $0.75 \mathrm{~g}$ of $R$. oryzae suspension, as well as 250,500 and 750 $\mu$ of $S$. cerevisiae were used as adsorbent, while rotated at speeds of $250 \mathrm{rpm}, 750 \mathrm{rpm}$ and 1500 rpm.

Biosorption of Saccharomyces cerevisiae and Rhizopus oryzae. The $\mathrm{Cr}^{6+}$ metal content was measured by UV-Vis spectrophotometer $\lambda$ $525 \mathrm{~nm}$. Subsequently, counting was performed using linear regression equation, with standard calibration curve (Zhang et al., 1998; Garg et al., 2007; Stănilă et al., 2015).

\section{RESULTS AND DISCUSSION}

The concentration of $\mathrm{Cr}^{6+}$ are rather low, thus, the standard calibration curve of $\mathrm{Cr}^{6+}$ solution was reconstructed using a narrower concentration range.

Meanwhile, the standards were measured with a UV-Vis spectrophotometer, at a wavelength of $525 \mathrm{~nm}$. The result (Table 1) showed an increase in standard solution's concentration, indicating a rise in absorbance. 
Table 1. Standard calibration curve of $\mathrm{Cr}^{6+}$.

\begin{tabular}{ll}
\hline Concentration $(\mathrm{mg} / \mathrm{L})$ & Absorbantion \\
\hline 0.3 & 0.174 \\
0.6 & 0.293 \\
0.9 & 0.403 \\
1.2 & 0.531 \\
1.5 & 0.621 \\
\hline
\end{tabular}

This is then translated into a calibration curve, using the linear equation $y=a x+b$, where $\mathrm{y}$ denotes absorbance value and $\mathrm{x}$ signifies concentration. The absorbance of standard solution was then used to determine the sample's concentration. Fig. 1 dan Fig. 2 shows the calibration curve obtained.

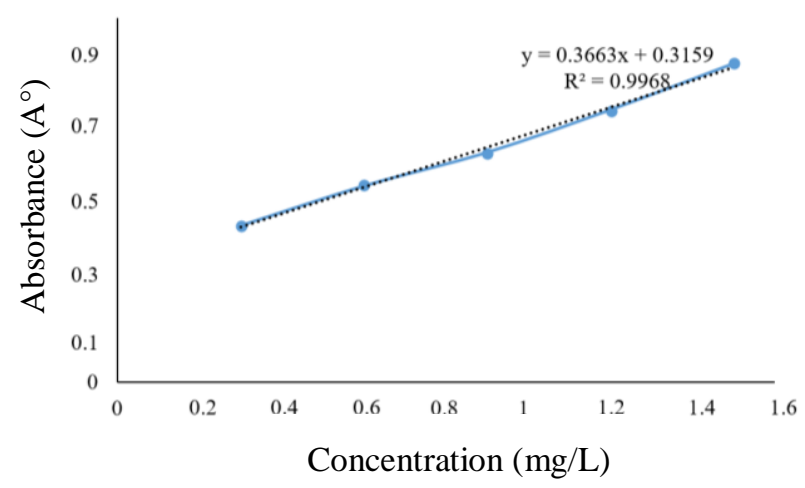

Fig. 1. Calibration curve for $\mathrm{Cr}^{6+} \lambda 525 \mathrm{~nm}$ with Saccharomyces cerevisiae.
Subsequently, the equation, $y=0.1163 x+$ 0.0723 , was applied to determine the levels of $\mathrm{Cr}^{6+}$ after biosorption with Rhizopus oryzae (Fig. 2).

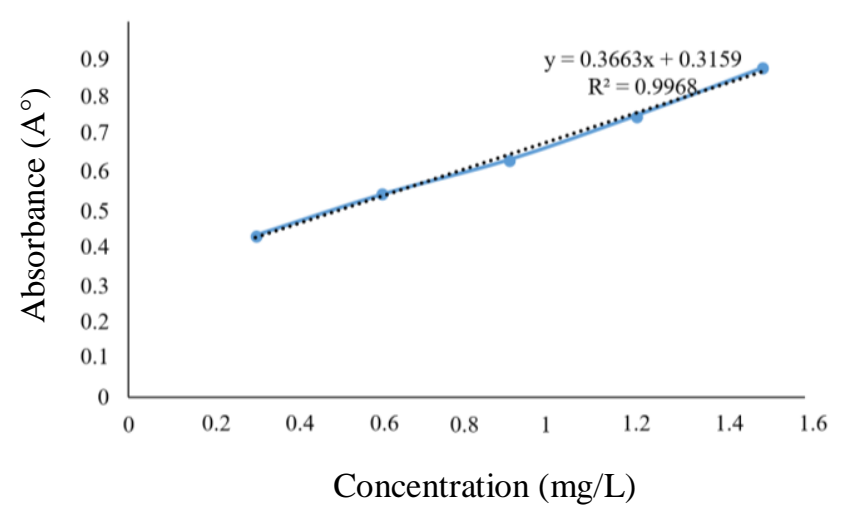

Fig. 2. Calibration curve for $\mathrm{Cr}^{6+} \lambda 525 \mathrm{~nm}$ with Rhizopus oryzae.

The first data and final of biosorption rate using Saccharomyces cerevisiae and Rhizopus oryzae showed in Table 2 and Table 3. The results presented in Table 2 shows that the highest adsorption was exhibited by $750 \mu$ of Saccharomyces cerevisiae in Nanjung and Pangauban, while the concentration of $\mathrm{Cr}^{+6}$ was reduced less using $250 \mu$ and $500 \mu$ of $S$. cerevisiae.

Table 2. The biosorption rate using Saccharomyces cerevisiae.

\begin{tabular}{|c|c|c|c|c|c|c|c|c|c|c|}
\hline \multirow{2}{*}{ Location } & \multirow{2}{*}{ Data } & \multicolumn{3}{|c|}{ Biomass $250 \mu$} & \multicolumn{3}{|c|}{ Biomass $500 \mu$} & \multicolumn{3}{|c|}{ Biomass $750 \mu$} \\
\hline & & Low & Med & $\mathrm{Hi}$ & Low & Med & $\mathrm{Hi}$ & Low & Med & $\mathrm{Hi}$ \\
\hline \multirow{4}{*}{$\begin{array}{l}\text { Citarum River } \\
\text { in Nanjung } \\
\text { Village }\end{array}$} & \multicolumn{10}{|c|}{ Absorbantion $\left(\mathrm{A}^{\circ}\right)$} \\
\hline & 0.931 & 0.53 & 0.690 & 0.657 & 0.547 & 0.543 & 0.531 & 0.465 & 0.460 & 0.409 \\
\hline & \multicolumn{10}{|c|}{ Concentration $(\mathrm{mg} / \mathrm{L})$} \\
\hline & 1.679 & 0.584 & 1.021 & 0.931 & 0.631 & 0.620 & 0.587 & 0.407 & 0.393 & 0.254 \\
\hline \multirow{3}{*}{$\begin{array}{l}\text { Citarum River } \\
\text { in Pangauban } \\
\text { Village }\end{array}$} & 0.883 & \multicolumn{7}{|c|}{ Absorbantion $\left(\mathrm{A}^{\circ}\right)$} & & \\
\hline & \multicolumn{10}{|c|}{ Concentration $(\mathrm{mg} / \mathrm{L})$} \\
\hline & 1.548 & 0.393 & 3.514 & 0.767 & 0.552 & 0.535 & 0.486 & 0.265 & 0.336 & 0.437 \\
\hline
\end{tabular}

According to Table 3, the concentration of $\mathrm{Cr}^{6+}$ was discovered to reduce after the adsorption process, and this reduction was observed with an increase in biomass. The highest adsorption was exhibited by $0.75 \mathrm{~g}$ of Rhizopus oryzae as the biosorbents in both Nanjung and Pangauban village. This indicates an increase in the number of fungi cell wall binding sites leads to increased $\mathrm{Cr}^{6+}$ biosorption. Bennett et al. (2013) stated that The majority of the cell wall binding sites were negatively charged, thus the positively charged $\mathrm{Cr}^{6+}$ was attracted to $-\mathrm{OH}$ and $\mathrm{C}=\mathrm{O}$ binding groups which responsible for the adsorption within the fungi biomass. In line with Luo et al. (2010), Xu et al., (2012), Espinoza-Sánchez et al. (2019) that Rhizopus sp. presented biosorption capacities of dry biomass for $\mathrm{Cr}^{6+}$. 
Table 3. The biosorption rate using Rhizopus oryzae.

\begin{tabular}{|c|c|c|c|c|c|c|c|c|c|c|}
\hline \multirow{2}{*}{ Location } & \multirow{2}{*}{ Data } & \multicolumn{3}{|c|}{ Biomass $0.25 \mathrm{~g}$} & \multicolumn{3}{|c|}{ Biomass $0.50 \mathrm{~g}$} & \multicolumn{3}{|c|}{ Biomass $0.75 \mathrm{~g}$} \\
\hline & & Low & Med & $\mathrm{Hi}$ & Low & Med & $\mathrm{Hi}$ & Low & Med & $\mathrm{Hi}$ \\
\hline \multirow{4}{*}{$\begin{array}{l}\text { Citarum River } \\
\text { in Nanjung } \\
\text { village }\end{array}$} & Absorbantion $\left(\mathrm{A}^{\circ}\right)$ & & & & & & & & & \\
\hline & 0.931 & 0.233 & 0.227 & 0.226 & 0.231 & 0.211 & 0.209 & 0.112 & 0.108 & 0.098 \\
\hline & Concentration (mg/l & & & & & & & & & \\
\hline & 1.679 & 1.382 & 1.330 & 1.322 & 1.366 & 1.195 & 1.175 & 0.341 & 0.307 & 0.221 \\
\hline \multirow{4}{*}{$\begin{array}{l}\text { Citarum River } \\
\text { in Pangauban } \\
\text { village }\end{array}$} & Absorbantion $\left(\mathrm{A}^{\circ}\right)$ & & & & & & & & & \\
\hline & 0.883 & 0.280 & 0.230 & 0.220 & 0.231 & 0.225 & 0.224 & 0.127 & 0.119 & 0.118 \\
\hline & Concentration $(\mathrm{mg} / \mathrm{l}$ & & & & & & & & & \\
\hline & 1.548 & 1.786 & 1.356 & 1.270 & 1.365 & 1.313 & 1.304 & 0.470 & 0.402 & 0.393 \\
\hline
\end{tabular}

The optimum percentage reduction in $\mathrm{Cr}^{6+}$ concentration, for the sample obtained from Nanjung village, at the highest stirring speeds, were $84.872 \%$, and $85.998 \%$, using $750 \mu$ of $S$. cerevisiae, and $0.75 \mathrm{~g}$ of $R$. oryzae respectively. As biosorbent mass increases, the percentage efficiency and competitive of the adsorption process also increases due to the rise in the number of available heavy metal binding sites on the biosorbent's surface (Li et al., 2016; Mahmoud \& Mohamed, 2017). Furthermore, stirring helps to renew the concentration gradient of the biosorbent interface with bulk biosorbate, hence, biosorption occurs continuously. Therefore, an increase stirring speed enlarges the contact zone between the biosorbent and bulk biosorbate.

Based on QS. Ali 'Imran verse 91 (Kementerian Agama RI, 2019a) that the sky and the earth and all living things on earth are signs of the existence and greatness of Allah swt. to create everything with a specific purpose, nothing is in vain. As intelligent creatures, humans are given the ability to take advantage of the universe and its contents for benefit. One illustration of the use of living things created by Allah swt. namely the use of microorganisms from the fungal group, namely Saccharomyces cerevisiae and Rhizopus oryzae, as biological agents for the biosorption process. The use of these two microorganisms is a lesson for us always to benefit others and the environment. Saccharomyces cerevisiae and Rhizopus oryzae with a tiny size can help for the biosorption process, reducing the environmental pollution. Humans should not only be the cause of earth damage, as described in QS. Ar-Rum verse 41 (Kementerian Agama RI, 2019b) but must be a true caliph who has been given a mandate by Allah swt. to provide suitable for the universe, who is responsible for himself, fellow humans, and the ecosystem or environment as implied in QS. Al-Ahzab verse 72 (Kementerian Agama RI, 2019c). Human life cannot be separated from various environmental components. Humans are responsible for maintaining the continuity, balance, and preservation of the environment, which is their life source.

\section{CONCLUSION}

Chromium(VI) levels in Citarum River water in is decreased by biosorbtion with Saccharomyces cerevisiae and Rhizopus oryzae. The optimum percentage reduction in $\mathrm{Cr}^{6+}$ concentration obtained, were $84.872 \%$, and $85.998 \%$, using $750 \mu$ of $S$. cerevisiae suspension, and $0.75 \mathrm{~g}$ of dry residue of $R$. oryzae, respectively. $S$. cerevisiae and $R$. oryzae have great potential as biosorbents for the in situ remediation of Citarum River contaminated with heavy metals.

\section{ACKNOWLEDGEMENTS}

This research is funded by Beginner Lecturer Research Grand from Ministry of Research and Technology/National Research and Innovation Agency, Republic Indonesia with the contract number of $2755 / \mathrm{L} 4 / \mathrm{PP} / 2019$.

\section{REFERENCES}

Abbas SH, Ismail IM, Mostafa TM, Sulaymon AH. 2014. Biosorption of heavy metals: a review. Journal of Chemical Science and Technology. vol 3(4): 74102.

Ameri A, Tamjidi S, Dehghankhalili F, Farhadi A, Saati MA. 2020. Application of algae as low cost and effective bio-adsorbent for removal of heavy metals from wastewater: a review study. Environmental Technology Reviews. vol 9(1): 85-110. doi: https://doi.org/10.1080/21622515.2020.1831619. 
Anirudhan TS, Sreekumari SS. 2011. Adsorptive removal of heavy metal ions from industrial effluents using activated carbon derived from waste coconut buttons. Journal of Environmental Sciences. vol 23(12): 1989-1998. doi: https://doi.org/10.1016/S1001-0742(10)60515-3.

Ayangbenro AS, Babalola OO. 2017. A new strategy for heavy metal polluted environments: a review of microbial biosorbents. International Journal of Environmental Research and Public Health. vol 14(1): 1-16. doi: https://doi.org/10.3390/ijerph14010094.

Ayob A, Santiagoo R, Amneera WA, Ismail N, Abdullah AZ. 2016. Ultrasonic-assisted synthesis of reactive carboxymethyl cellulose stabilized nano zerovalent iron and its application for removal of $\mathrm{Cr}^{6+}$ and $\mathrm{Cu}^{2+}$ ions. Environment Protection Engineering. vol 42(2): 55-79. doi: https://doi.org/10.5277/epe160204.

Badan Pusat Statistik Provinsi Jawa Barat. 2016. Jumlah industri besar sedang menurut subsektor industri menurut golongan industri di Jawa Barat, 20102014. Bandung: BPS Provinsi Jawa Barat, Indonesia. https://jabar.bps.go.id/.

Bakircioglu D, Ucar G, Kurtulus YB. 2011. Coliform bacteria immobilized on titanium dioxide nanoparticles as a biosorbent for trace lead preconcentration followed by atomic absorption spectrometric determination. Microchimica Acta. vol 174(3-4): 367-374. doi https://doi.org/10.1007/s00604-011-0630-3.

Bennett RM, Cordero PRF, Bautista GS, Dedeles GR. 2013. Reduction of hexavalent chromium using fungi and bacteria isolated from contaminated soil and water samples. Chemistry and Ecology. vol 29(4): 320-328. doi: https://doi.org/10.1080/02757540.2013.770478.

Chatterjee SK, Bhattacharjee I, Chandra G. 2010. Biosorption of heavy metals from industrial waste water by Geobacillus thermodenitrificans. Journal of Hazardous Materials. vol 175(1-3): 117-125. doi: https://doi.org/10.1016/j.jhazmat.2009.09.136.

Chojnacka K. 2010. Biosorption and bioaccumulationthe prospects for practical applications. Environment International. vol 36(3): 299-307. doi: https://doi.org/10.1016/j.envint.2009.12.001.

Das J, Sarkar A, Sil PC. 2015. Hexavalent chromium induces apoptosis in human liver (HepG2) cells via redox imbalance. Toxicology Reports. vol 2: 600608.

doi: https://doi.org/10.1016/j.toxrep.2015.03.013.

do Nascimento JM, de Oliveira JD, Rizzo ACL, Leite SGF. 2019. Biosorption $\mathrm{Cu}$ (II) by the yeast Saccharomyces cerevisiae. Biotechnology Reports. vol 21: 1-7. doi: https://doi.org/10.1016/j.btre.2019.e00315.

Dhankhar R, Hooda A. 2011. Fungal biosorption-an alternative to meet the challenges of heavy metal pollution in aqueous solutions. Environmental Technology. vol 32(5): 467-491. doi: https://doi.org/10.1080/09593330.2011.572922.

Escudero LB, Quintas PY, Wuilloud RG, Dotto GL. 2019. Recent advances on elemental biosorption. Environmental Chemistry Letters. vol 17(1): 409427. doi: https://doi.org/10.1007/s10311-018-08166.

Espinoza-Sánchez MA, Arévalo-Niño K, QuinteroZapata I, Castro-González I, Almaguer-Cantú V. 2019. Cr (VI) adsorption from aqueous solution by fungal bioremediation based using Rhizopus sp. Journal of Environmental Management. vol 251: 18. doi: https://doi.org/10.1016/j.jenvman.2019.109595.

Farhan SN, Khadom AA. 2015. Biosorption of heavy metals from aqueous solutions by Saccharomyces cerevisiae. International Journal of Industrial Chemistry. vol 6(2): 119-130. doi: https://doi.org/10.1007/s40090-015-0038-8.

Fasya AHZ. 2018. The incidence of dermatitis analysis based on individual characteristics of metal plating workers in Sidoarjo. Jurnal Kesehatan Lingkungan . vol 10(2): 149-158. doi: http://dx.doi.org/10.20473/jkl.v10i2.2018.149-158.

Favaro L, Jansen T, van Zyl WH. 2019. Exploring industrial and natural Saccharomyces cerevisiae strains for the bio-based economy from biomass: the case of bioethanol. Critical Reviews in Biotechnology. vol 39(6): 800-816. doi: https://doi.org/10.1080/07388551.2019.1619157.

Fu YQ, Li S, Zhu HY, Jiang R, Yin LF. 2012. Biosorption of copper (II) from aqueous solution by mycelial pellets of Rhizopus oryzae. African Journal of Biotechnology. vol 11(6): 1403-1411. doi: https://doi.org/10.5897/AJB11.2809.

Garg UK, Kaur MP, Garg VK, Sud D. 2007. Removal of hexavalent chromium from aqueous solution by agricultural waste biomass. Journal of Hazardous Materials. vol 140(1-2): 60-68.

Gharieb MM, Al-Fakih AA, Ali MI. 2014. Biosorption of $\mathrm{Pb}$ (II) and $\mathrm{Co}$ (II) ions from aqueous solutions using pretreated Rhizopus oryzae (bread mold). Arabian Journal for Science and Engineering. vol 39(4): 2435-2446. doi: https://doi.org/10.1007/s13369-013-0784-x.

Gupta A, Yadav R, Devi P. 2011. Removal of hexavalent chromium using activated coconut shell and activated coconut coir as low cost adsorbent. The IIOAB Journal. vol 2(3): 8-12.

Gürel L. 2017. Applications of the biosorption process for nickel removal from aqueous solutions-A review. Chemical Engineering Communications. vol 204(6): 711-722. doi: https://doi.org/10.1080/00986445.2017.1306698.

Igberase E, Osifo P, Ofomaja A. 2018. Adsorption of metal ions by microwave assisted grafting of crosslinked chitosan beads. Equilibrium, isotherm, thermodynamic and desorption studies. Applied Organometallic Chemistry. vol 32(3): 1-14. doi: https://doi.org/10.1002/aoc.4131.

Jabbo JN, Ugodulunwa FXO, Yusuf UM, Maiauduga 
NA, Gin NS, Usman AM, Gani SJ, Dung SG. 2016. Water Quality Assessment of Some Selected Hand Dug Wells and a Borehole in North Eastern Parts of Bauchi Metropolis, Nigeria. Journal of Environment and Earth Science. vol 6(6): 137-145.

Kementerian Agama RI. 2019a. Terjemahan Al Qur'an Surat Ali 'Imran ayat 91. https://quran.kemenag.go.id/.

Kementerian Agama RI. 2019b. Terjemahan Al Qur'an Surat QS. Ar-Rum ayat 41. https://quran.kemenag.go.id/.

Kementerian Agama RI. 2019c. Terjemahan Al Qur'an Surat QS. Al-Ahzab ayat 72. https://quran.kemenag.go.id/.

Kılıç Z, Atakol O, Aras S, Cansaran-Duman D, Emregul E. 2014. Biosorption properties of zinc (II) from aqueous solutions by Pseudevernia furfuracea (L.) Zopf. Journal of the Air \& Waste Management Association. vol 64(10): 1112-1121. doi: https://doi.org/10.1080/10962247.2014.926299.

Kim JH, Kang JC. 2016. Oxidative stress, neurotoxicity, and metallothionein (MT) gene expression in juvenile rock fish Sebastes schlegelii under the different levels of dietary chromium $\left(\mathrm{Cr}^{6+}\right)$ exposure. Ecotoxicology and Environmental Safety. vol 125: 78-84. doi: https://doi.org/10.1016/j.ecoenv.2015.12.001.

Komarawidjaja W. 2016. Sebaran limbah cair industri tekstil dan dampaknya di beberapa desa Kecamatan Rancaekek Kabupaten Bandung. Jurnal Teknologi Lingkungan. vol 17(2): 118-125. doi: https://doi.org/10.29122/jtl.v17i2.1045.

Kozlowski H, Kolkowska P, Watly J, Krzywoszynska K, Potocki S. 2014. General aspects of metal toxicity. Current Medicinal Chemistry. vol 21(33): 37213740 .

doi: https://doi.org/10.2174/0929867321666140716093 838.

Lazo P. 2009. Determination of Cr (VI) in environmental samples evaluating $\mathrm{Cr}$ (VI) impact in a contaminated area. Journal of International Environmental Application \& Science. vol 4(2): 207-213.

Lembaga Ilmu Pengetahuan Indonesia. 2019. Upaya LIPI mewujudkan pemulihan Citarum. Bandung: Lembaga Ilmu Pengetahuan Indonesia (LIPI). http://lipi.go.id/.

Li D, Han J. 2019. Homogeneous photocatalytic iron slag reduction $\mathrm{Cr}^{6+}$ from chromium wastewater containing high-salt in Constructed Wetland. Polish Journal of Environmental Studies. vol 28(5): 37453752. doi: https://doi.org/10.15244/pjoes/94815.

Li Y, Liu J, Yuan Q, Tang H, Yu F, Lv X. 2016. A green adsorbent derived from banana peel for highly effective removal of heavy metal ions from water. Rsc Advances. vol 6(51): 45041-45048. doi: https://doi.org/10.1039/C6RA07460J.

Luo JM, Xiao XIAO, Sheng-lian LUO. 2010. Biosorption of cadmium (II) from aqueous solutions by industrial fungus Rhizopus cohnii.
Transactions of nonferrous metals society of China. vol 20(6): 1104-1111. doi: https://doi.org/10.1016/S1003-6326(09)60264-8.

Mahmoud MS, Mohamed SA. 2017. Calcium alginate as an eco-friendly supporting material for Baker's yeast strain in chromium bioremediation. HBRC Journal. vol 13(3): 245-254. doi: https://doi.org/10.1016/j.hbrcj.2015.06.003.

Paramita RW. 2017. Kandungan logam berat kadmium (Cd) dan kromium (Cr) di air permukaan dan sedimen: studi kasus Waduk Saguling Jawa Barat. Jurnal Reka Lingkungan. vol 5(2): 1-12. doi: https://doi.org/10.26760/rekalingkungan.v5i2.\%25 p.

Priyanto B. 2019. Penerapan uji hayati dengan Lemna sp. untuk mengkaji kualitas air sungai yang menerima air limbah industri tekstil di Kabupaten Bandung. Jurnal Hidrosfir Indonesia. vol 4(3): 1-7.

Proctor DM, Suh M, Campleman SL, Thompson CM. 2014. Assessment of the mode of action for hexavalent chromium-induced lung cancer following inhalation exposures. Toxicology. vol 325: 160-179. doi: https://doi.org/10.1016/j.tox.2014.08.009.

Putra DM. 2017. Kontribusi industri tekstil dalam penggunaan bahan berbahaya dan beracun terhadap rusaknya sungai Citarum. Jurnal Hukum Lingkungan Indonesia. vol 3(1): 133-152. doi: http://dx.doi.org/10.38011/jhli.v3i1.37.

Rice EW, Baird RB, Eaton AD. 2017. Standard methods for the examination of water and wastewater, $23^{\text {rd }}$ edition. Washington DC: American Public Health Association, American Water Works Association, Water Environment Federation. pp. 3-73.

Sathvika T, Soni A, Sharma K, Praneeth M, Mudaliyar M, Rajesh V, Rajesh N. 2018. Potential application of Saccharomyces cerevisiae and Rhizobium immobilized in multi walled carbon nanotubes to adsorb hexavalent chromium. Scientific Reports. vol 8(1): 1-13. doi: https://doi.org/10.1038/s41598018-28067-9.

Siddiquee S, Rovina K, Azad SA, Naher L, Suryani S, Chaikaew P. 2015. Heavy metal contaminants removal from wastewater using the potential filamentous fungi biomass: a review. Journal of Microbial \& Biochemical Technology. vol 7(6): 384-395.

Sihombing AK. 2020. Penegakan hukum terhadap pencemaran lingkungan di Sungai Cikijing, Jawa Barat akibat aktivitas industri tekstil PT. Kahatex. Jurnal Hukum Lingkungan Indonesia. vol 7(1): 98117. doi: http://dx.doi.org/10.38011/jhli.v7i1.209.

Son EB, Poo KM, Mohamed HO, Choi YJ, Cho WC, Chae KJ. 2018. A novel approach to developing a reusable marine macro-algae adsorbent with chitosan and ferric oxide for simultaneous efficient heavy metal removal and easy magnetic separation. Bioresource Technology. vol 259: 381-387. doi: https://doi.org/10.1016/j.biortech.2018.03.077.

Stănilă A, Mihăiescu T, Odagiu A. 2015. Studies 
Regarding Cytotoxicity of Copper, Lead and Zinc Ions Solutions on Living Saccharomices Cerevisae Cells. ProEnvironment Promediu. vol 8(23): 445450.

Sumantri A, Rahmani RZ. 2018. Analisis pencemaran kromium (VI) berdasarkan kadar chemical oxygen demand (COD) pada hulu sungai Citarum di Kecamatan Majalaya Kabupaten Bandung Provinsi Jawa Barat. Jurnal Kesehatan Lingkungan Indonesia. vol 19(2): 144-151. doi: https://doi.org/10.14710/jkli.19.2.144-151.

Tahir A, Lateef Z, Abdel-Megeed A, Sholkamy EN, Mostafa AA. 2017. In vitro compatibility of fungi for the biosorption of zinc (II) and copper (II) from electroplating effluent. Current Science. vol 112(4): 839-844.

Vellaichamy B, Periakaruppan P, Nagulan B. 2017. Reduction of $\mathrm{Cr}^{6+}$ from wastewater using a novel in situ-synthesized $\mathrm{PANI} / \mathrm{MnO} 2 / \mathrm{TiO}_{2}$ nanocomposite: renewable, selective, stable, and synergistic catalysis. ACS Sustainable Chemistry \& Engineering. vol 5(10): 9313-9324. doi: https://doi.org/10.1021/acssuschemeng.7b02324.

Wardani E. 2018. Identifikasi pencemaran logam berat raksa di sungai citarum hulu Jawa Barat. Jurnal Teknik Kimia Indonesia. vol 8(1): 17-23. doi: https://doi.org/10.5614/jtki.2009.8.1.4.
Xie J, Feng N, Wang R, Guo Z, Dong H, Cui H, Wu H, Qiu G, Liu X. 2020. A reusable biosorbent using Ca-Alginate immobilized Providencia vermicola for Pd (II) recovery from acidic solution. Water, Air, \& Soil Pollution. vol 231(2): 1-12. doi: https://doi.org/10.1007/s11270-020-4399-z.

Xu M, Yin P, Liu X, Tang Q, Qu R, Xu Q. 2013. Utilization of rice husks modified by organomultiphosphonic acids as low-cost biosorbents for enhanced adsorption of heavy metal ions. Bioresource Technology. vol 149: 420-424. doi: https://doi.org/10.1016/j.biortech.2013.09.075.

Xu X, Xia L, Huang Q, Gu JD, Chen W. 2012. Biosorption of cadmium by a metal-resistant filamentous fungus isolated from chicken manure compost. Environmental Technology. vol 33(14): 1661-1670. doi: https://doi.org/10.1080/09593330.2011.641591.

Zewail TM, Yousef NS. 2014. Chromium ions $\left(\mathrm{Cr}^{6+}\right.$ \& $\mathrm{Cr}^{3+}$ ) removal from synthetic wastewater by electrocoagulation using vertical expanded $\mathrm{Fe}$ anode. Journal of Electroanalytical Chemistry. vol 735: 123-128. doi: https://doi.org/10.1016/j.jelechem.2014.09.002.

Zhang LI, Zhao LI, Yu Y, Chen C. 1998. Removal of lead from aqueous solution by non-living Rhizopus nigricans. Water Research. vol 32(5): 1437-1444. 